\title{
Premalignant Lesion
}

National Cancer Institute

\section{Source}

National Cancer Institute. Premalignant Lesion. NCI Thesaurus. Code C42624.

A lesion characterized by the proliferation of atypical or dysplastic cells without evidence of stromal invasion. 